\title{
Physicochemical characterization of leachates produced in the Rabat-Salé-Kénitra Region landfill technical center and monitoring of their treatment by aeration and reverse osmosis
}

\author{
Mounaim Halim El Jalil ${ }^{1, *}$, Hind Elkrauni ${ }^{1}$, Mohamed Khamar $^{1}$, Abdelhakim Bouyahya ${ }^{2}$, Hecham \\ Elhamri $^{3}$, Essediya Cherkaoui ${ }^{1}$, and Abderrahman Nounah $^{1}$ \\ ${ }^{11}$ Civil Engineering and Environment Laboratory (LGCE). Materials Water and Environment team, High School of \\ Technology, Sale, Morocco \\ ${ }^{2}$ Laboratoire de Biologie, Faculté des Sciences, Université Mohammed V de Rabat, Maroc. \\ ${ }^{3}$ Département de Toxicologie et d'Hydrologie, Institut National d'Hygiène du Maroc.
}

\begin{abstract}
The aim of this work is to study the physicochemical characterization and monitoring of the treatment of leachate generated by the landfilling of household and similar waste in the landfill of Rabat-SaléKénitra Region. The analysis of the results showed a high concentration of easily biodegradable organic matter. The pollutant load is of the order of $3,850 \mathrm{mg} / \mathrm{L}$ of the chemical oxygen demand (COD), $1.260 \mathrm{mg} / \mathrm{L}$ of the biochemical oxygen demand (BOD5), and shows an average content of nitrates $(\mathrm{NO}-=56.6 \mathrm{mg} / \mathrm{L})$. This mineral pollution is caused by a high electrical conductivity, which reaches an average value of $15.9 \mathrm{mS} / \mathrm{cm}$, and a low concentration of heavy metals in the raw leachate such as lead $(\mathrm{Pb}=1.591 \mathrm{mg} / \mathrm{L})$, copper $(\mathrm{Cu}=1.017 \mathrm{mg} / \mathrm{L})$, and cadmium $(\mathrm{Cd}=0.109 \mathrm{mg} / \mathrm{L})$. The biological treatment allows for the successive biodegradation of $40 \%$ of the BOD5, and $33 \%$ of the COD. Moreover, the reverse osmosis filtration in organic membranes achieves a reduction of $98 \%$ for BOD5, $97 \%$ for COD, $85 \%$ for lead, and $67 \%$ for copper. In this study, biological and reverse osmosis treatments represented an effective treatment for the organic and metallic leachate pollutants of this landfill.
\end{abstract}

Key words: Household waste, Landfill technical center, Leachate, Biological treatment, Reverse osmosis treatment.

\section{Introduction}

The management of household and similar waste is one of the main challenges facing the Morocco. The combination of a set of factors such as population growth, urban expansion, the development of socioeconomic and production activities, as well as changes lifestyles and consumption, generates a growing deposit of solid and liquid waste [1].

For the vast majority of Moroccan local authorities, the management of this waste remains a priority challenge and weighs heavily on communal budgets. The increased quantities of waste due to rapid urbanization pose a series of challenges such as:

- The increase in the cost of waste collection linked to the increase in the daily tonnage of waste produced ;

- Saturation of landfills, which constitutes a major challenge given the limitation of available land and suitable for setting up new controlled landfills ;

- The environmental impact caused by waste collection (CO2 emissions), discharge (greenhouse gas emissions) and leachate discharges (potential pollution of water or groundwater) ;

- The toxicity of certain substances emitted by these installations is proven and humans can be exposed to these pollutants in multiple ways.

This situation is all the more worrying due to the lack of empirical data on the composition of waste at local level. This constitutes a constraint for the implementation at the level local policy to reduce the amount of waste landfilled through treatment, recycling or valuation [2].

Currently, the landfill technical center (LTC) of Oum Azza receives almost 850,000 tons/year of household and similar waste (HSW) from 13 municipalities in the Rabat-Salé-Kénitra (RSK) region of the Kingdom of Morocco. These wastes are composed of more than $60 \%$ of very wet organic waste (50 to $60 \%$ of water), and have a low calorific value of less than $900 \mathrm{kcal} / \mathrm{kg}$ [1].

The daily arrival of 2,000 tons of HSW at the Oum Azza LTC generates the highest quantity of leachates, almost $480 \mathrm{~m} 3 /$ day [2]. The exploitation of the Oum Azza landfill began on 7 December 2007 by the French multinational Group PIZZORNO, and it is the first nationally controlled landfill. It receives the waste of the 13 municipalities of the Region, including large

Corresponding author: $\underline{\text { mheljalil@yahoo.fr }}$ 
communes such as Rabat, Sale and Temara, and small towns such as Skhirat, Harhoura, and Bouknadel.

Three intermediate HSW transfer centers feed the Oum Azza LTC (Rabat, Salé, and Temara transfer center). After 10 years of exploitation, the controlled landfill of the RSK region is among the sites that suffer the most from the leachate problem. The systems of natural evaporation, intentional evaporation, biological treatment, and reverse osmosis have been set up to reduce leachates, but their performance remains very low. Indeed, in September 2019, the quantities stored reached an order of $230.000 \mathrm{~m} 3$, representing a real threat to the water table.

In this context, the aim of our study was to compare the capacity and the performance of the LTC of Oum Azza with those of its counterparts in other large cities of Morocco, and explore these produced leachates as well as the efficiency of their treatment.

\section{Materials and Methods}

\subsection{Landfill Center of Oum Azza}

The site of Oum Azza is located in the RSK region about $30 \mathrm{~km}$ south-west of Rabat city. The site is located between the villages of Oum Azza $(1.5 \mathrm{Km})$ and Ain El Aouda (less than $1 \mathrm{Km}$ ). It is bordered in the north by the Rabat city (capital of the Morocco kingdom) and in the south by the Ain El Aouda village. The center is monitoring the evaluation of material flows sorted by the waste collectors of the former Eukrech waste dump, which is now organized into a cooperative known as Attaouafouk. After their collection and their weighing at the entrance of the center, the vehicles evacuate their leachates in the network dedicated to these effluents and then unload the HSW in two receiving pits at the LTC.

The matters are sorted according to several parameters, such as their nature, their quality and their granulometry [4]. In addition, the recycling rate of waste at the level of the Oum Azza LTC covers only 10\% of the total quantity of waste, the remaining $90 \%$ being carried away to landfill sites for burial or landfills, or even abandoned in the wild. Within the $10 \%$ of the waste that is recycled, $7 \%$ is used for producing energy thanks to an innovative and pioneering partnership with the Lafarge Holcim Group (large cement plant in Morocco). This waste is used as solid recovered fuel (SRF), and only $3 \%$ is recycled and valorized such as wood, glass, and some types of plastic.

\subsection{Benchmark study}

At the beginning of our investigation, a benchmark study was conducted to compare the performances of the LTC of Oum Azza with other LTCs recently established in the large cities of Morocco. To this end, several visits were made to the landfill sites of the cities of Oujda, Meknes, Fez, Marrakech, Casablanca, and Rabat (the Oum Azza LTC) (Figure 1). To compare the performances of the different visited LTCs, several indicators relating to the size of each LTC and to the extent of application of waste treatment and recovery techniques were adopted. The compared indicators include the start date of the site operation, the quantity of waste received per day, the treatment price in $\$ /$ ton, the sorting line, the technical burial of waste, leachate treatment, odor treatment, biogas recovery, electric cogeneration, solid recovered fuel (SRF), composting, and methanation.

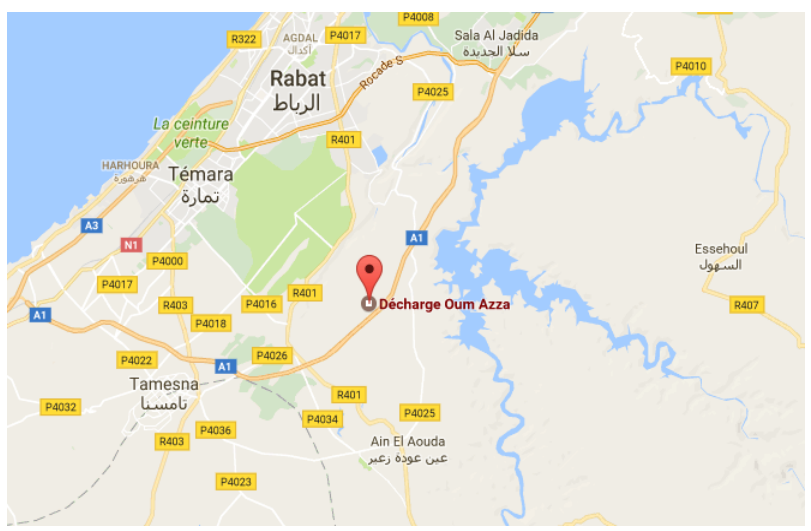

Figure 1: Localisation map of Oum Azza landfill technical center

\subsection{Sampling campaign of Oum Azza LTC}

The physicochemical analyses carried out in May 2019 on these leachates allowed the distinction between three types of effluents according to their age and their chemical composition, in particular their degree of salinity.

The sampling of leachates was carried out at the Oum Azza landfill in April 2019. Three batches of samples were taken. A batch of 10 samples of young leachates in their raw state (S1), a batch of 10 samples of leachates leaving the aerated basins (S2), and a batch of 10 samples of leachates at the exit of the reverse osmosis station (S3). The samples were taken from polyethylene bottles previously washed with the sample. An amount of nitric acid was added to the vials to secure the samples that were stored in a cooler during transport to the laboratory and analyzed within 24 hours.

Several physicochemical parameters were measured such as $\mathrm{pH}$ (using a $\mathrm{pH}$ meter WTW $\mathrm{pH}$ 522), and electrical conductivity (using a $\mathrm{HACH}$ model 44600 conductivity meter). Moreover, the measurement of organic elements such as COD, BOD5, suspended solids (SS), and heavy metal measurements (Aluminum, Lead, Copper and Cadmium) were carried out in the environmental laboratory of the National Institute of Hygiene (INH).

\subsection{Studied parameters}

\subsubsection{Pollution parameters}

During the test, the main indicators of pollution were studied. They include temperature, $\mathrm{pH}$, electrical conductivity (EC), suspended solids (SS), carbon oxygen demand (COD), biochemical oxygen demand (BOD5), and nitrogen. These analyses were performed using a PASTER UV multifunctional device, and all the used methods are validated by AFNOR.

\subsubsection{Heavy metals}

Corresponding author: mheljalil@yahoo.fr 
The assay of heavy metals was carried out using an atomic absorption spectrometer. After the cleaning of materials, a very important step of destruction and digestion of the organic matter was applied by thermal etching. A dilution of $25 \mathrm{~mL}$ was made before the filling of the tanks and the measuring in the device.

\section{Results and discussion}

\subsection{Benchmark study}

The results of the study visits to the LTC of Oum Azza and the five main LTCs of the cities of Fez [3], Meknes [4], Oujda [5], Marrakech [6] and Casablanca [7] allowed the update of technical information on the quantities of waste and the technical measures applied thereon, including the latest data reported by Allix [2].

The results reported concerning the treatment of leachates revealed the arrival of more than 2.000 tons/d of waste at the Oum Azza LTC, generating $400 \mathrm{~m}^{3} / \mathrm{d}$. The produced quantities are accumulated pending an agreement between the delegating authorities and the delegated company on the cost of the treatment. In addition, a gravity collection device is used, along with a treatment in aeration basins and then reverse osmosis. Subsequently, the permeate $(60 \%)$ is released into a natural reservoir nearby, while the concentrate $(40 \%)$ is stored in retention ponds. According to the managers of the delegated company, the leachate production data, displayed in the specifications, do not reflect reality. Consequently, the lack of a perennial and inexpensive solution to treat the leachate quantities produced causes a real problem, especially after the accumulation of $230.000 \mathrm{~m} 3$ in the site basins (Table 1).

Concerning the platform for sorting household waste downstream (400 tons/day), the study revealed that there are two sorting lines at the Oum Azza LTC, with a chain conveyor and a rotary screen for the rough sorting of organic matter, manual removal of recyclable materials (mainly metals and plastics) on two conveyor belts, and finally a storage area (in piles in compartments).

To valorize this green waste, which represents more than 80.000 tons/year, it is mainly transferred to the Oum Azza LTC by a specific company. They are stored separately in swaths and then crushed into chips for sale to the Swiss Éléphant Vert Group for the production of organic fertilizers sold on the local market. The quantities of green waste recycled annually represent $10 \%$ of the total annual quantity of HSW received by the LTC.
Moreover, the Oum Azza LTC applies several techniques to fight against bad odors. Indeed, it is the only center among the four studied that applies a technique to fight against bad smells. These are caused by the storage of large quantities of leachates in basins for their treatment by evaporation and biological treatment. The proximity of local residents and the evolution of urban planning in recent years have posed an odor problem that does not appear on the specifications.

Of the nine techniques used in the LTCs, the Oum Azza LTC applies four and thus exceeds all visited LTCs. Indeed, the Oum Azza LTC is the only one that has two sorting lines with a recycling rate of $10 \%$ of the total quantities of received HSW, of which $3 \%$ are recycled like wood, glass and certain types of plastic, while more than 90.000 tons/year (almost 10\%) are recovered as solid recovered fuel. Moreover, the green waste, which represents $10 \%$ of the received waste, is valorized by composting. Finally, the Oum Azza LTC is the only center that applies a method to fight against bad odors. In addition, $80 \%$ of the remaining HSW is evacuated to landfill bins. Finally, the LTC of Meknes is the only one that treats the produced leachates [4].

\subsection{Leachates analysis}

The results of the physicochemical analyses of the studied leachates at different phases of their treatment are presented in Table 2. The evaluation of the performances of treatment by aeration then by reverse osmosis of the leachates from fresh household waste was based on the calculation of the abatements (purification yields) of certain parameters such as $\mathrm{pH}$, temperature, COD, BOD5, suspended matters, total nitrogen, and electrical conductivity. These parameters are indicators of treatment effectiveness.

\subsection{1. $\mathrm{pH}$}

The leachates $\mathrm{pH}$ variation in different phases of their treatment is shown in Figure 2. As indicated, leachate $\mathrm{pH}$ values vary between 7 and 8.2, which clearly show their alkaline and neutral characteristics. These results are of the same order of magnitude as those reported by El Bada et al. [8]. In addition, the $\mathrm{pH}$ values obtained in leachates could be related to the low concentration of volatile organic compounds. Indeed, during acid fermentation, the first phase of the anaerobic decomposition of waste, young percolates are rich in volatile organic compounds.

Corresponding author: mheljali1@yahoo.fr 
Table1: Benchmark of principal landfill technical center and the valorization of Morocco in 2019

\begin{tabular}{|c|c|c|c|c|c|c|c|c|c|c|c|c|c|}
\hline 章 & 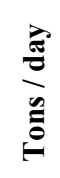 & 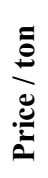 & 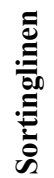 & 泀 & 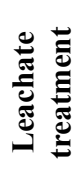 & 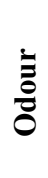 & $\begin{array}{l}\mathscr{E}_{00}^{0} \\
\stackrel{0}{0}\end{array}$ & 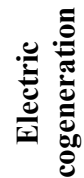 & $\frac{a}{\sqrt{S}}$ & 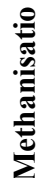 & & 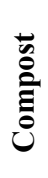 & $\stackrel{\theta}{\nu}$ \\
\hline
\end{tabular}

\begin{tabular}{|c|c|c|c|c|c|c|c|c|c|c|c|c|c|c|}
\hline Oujda & 2010 & 400 & 100 & NA & A & NA & NA & A & A & NA & NA & NA & 3 & 6 \\
\hline Meknès & 2016 & 400 & 140 & NA & A & A & NA & NA & NA & NA & NA & A & 3 & 6 \\
\hline Fès & 2005 & 700 & 90 & NA & $\mathrm{A}$ & NA & NA & A & A & $\mathrm{NA}$ & NA & NA & 3 & 6 \\
\hline Marrakech & 2017 & 800 & 180 & NA & A & NA & NA & NA & NA & NA & NA & NA & 1 & 8 \\
\hline Casablanca & 2009 & 3000 & 85 & NA & A & NA & $\mathrm{NA}$ & NA & NA & $\mathrm{NA}$ & NA & NA & 1 & 8 \\
\hline Oum Azza & 2007 & 2000 & 68 & A & A & NA & $\mathrm{A}$ & A & NA & A & NA & NA & 5 & 4 \\
\hline
\end{tabular}

SFR : Solid fuels recovery ; A : Treatment process applied ; NA : Treatment process not applied

Table 2: Evolution of the physicochemical parameters of leachate in the different phases of their treatment

Lot / parameter

(S1)
Lot of Leachates at the exit of the aeration basin

(S2)

\begin{tabular}{llll}
\hline pH & $8.20 \pm 0.74$ & $8.02 \pm 0.57$ & $7.00 \pm 0.35$ \\
Temprature $(\mathbf{T})\left({ }^{\circ} \mathbf{C}\right)$ & $20 \pm 0.4$ & $22 \pm 0.5$ & $19 \pm 0.1$ \\
COD (mg/L) & $3850 \pm 536$ & $2560 \pm 278$ & $129 \pm 36$ \\
BOD5 (mg/L) & $1260 \pm 213$ & $840 \pm 109$ & $42 \pm 11$ \\
Conductivity (mS/cm) & $15.9 \pm 2.1$ & $14.2 \pm 1.5$ & $2.1 \pm 0.7$ \\
SM (mg/L) & $2280 \pm 850$ & $1470 \pm 515$ & $97 \pm 42$ \\
COT (mg/L) & $1640 \pm 478$ & $1070 \pm 230$ & $62 \pm 28$ \\
NO3 (mg/L) & $159 \pm 89$ & $<1$ & $<1$ \\
\hline
\end{tabular}

Lot of leachates at the exit of inverse osmosis (S3)

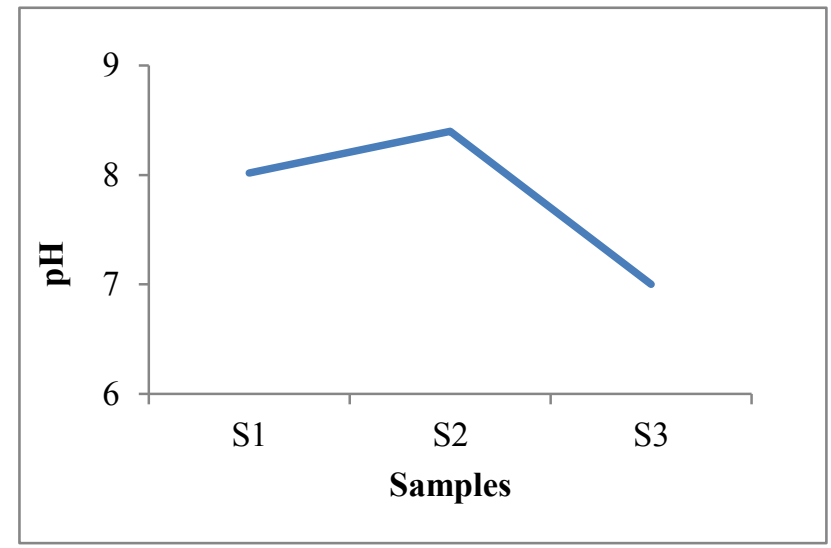

Figure 2: $\mathrm{pH}$ variation

\subsubsection{Temperature}

The average temperature of $20^{\circ} \mathrm{C}$ is quite characteristic of the month during which the samples were taken. The recorded temperatures are favorable to the maintenance of mesophilic groups of microorganisms, which develop at a temperature between 20 and $40^{\circ} \mathrm{C}$ [8,9], particularly in raw leachates and the aeration basin (Table 2).

\subsubsection{Conductivity}

The variation in leachate conductivity is illustrated in Figure 3. The high conductivity is noted in the raw leachate at $15.9 \mathrm{mS} / \mathrm{cm}$. It is higher than that obtained in the landfill of the city of Azemmour, which is 11.61

Corresponding author: mheljalil@yahoo.fr 
$\mathrm{mS} / \mathrm{cm}$ [8]. The biological treatment achieves a reduction rate of $12 \%$ for an average of $14.2(\mathrm{mS} / \mathrm{cm})$. Indeed, the bacteria are unable to degrade a significant amount of salts, while the reverse osmosis filtration reaches a rate of $98 \%$ reduction because the filters eliminate all types of minerals $(2.1 \mathrm{mS} / \mathrm{cm})$.

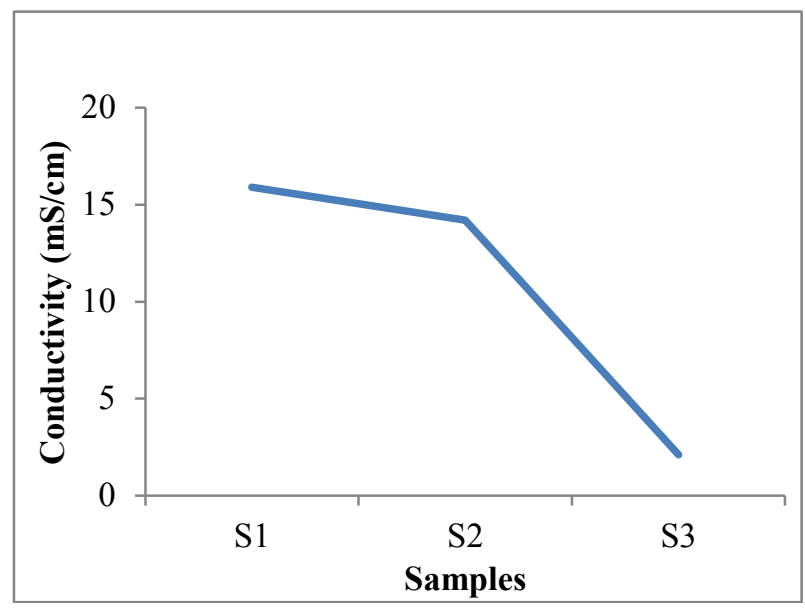

Figure 3: Conductivity

\subsection{4. $C O D$ and $B O D 5$}

The COD is used to evaluate the pollutant load of the wastewater and to check their compliance with the discharge standards. As shown in Figure 4, there is a significant decrease in leachate COD values in the aeration basins. Indeed, they decreased from an average of $3850 \mathrm{mg} / \mathrm{L}$ to $2560 \mathrm{mg} / \mathrm{L}$ and, then drastically decreased after reverse osmosis to an average of $129 \mathrm{mg} / \mathrm{L}$, with reduction rates of $33 \%$ and $95 \%$, respectively. BOD5 is an indicator of organic water pollution. It expresses the level of biodegradability of the effluent.

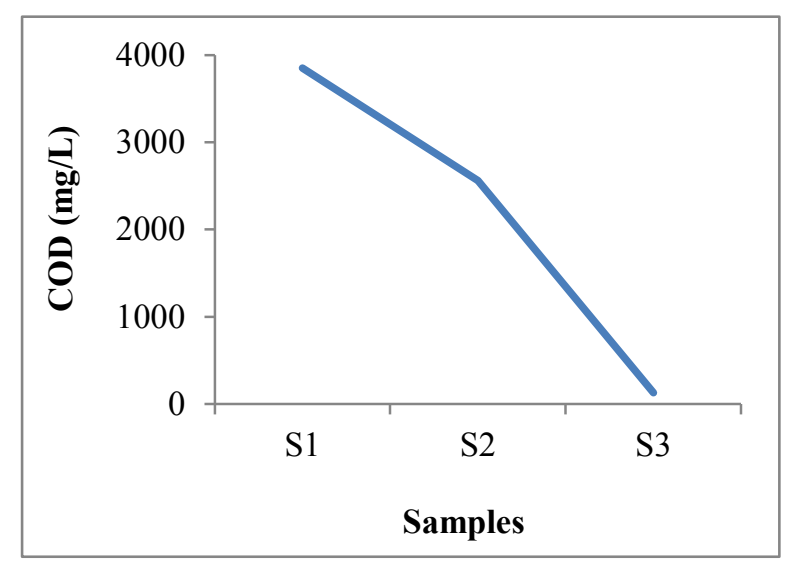

Figure 4: COD

Figure 5 illustrates the variation of the BOD5 content of the leachates studied. It is noted that the average value of BOD5 of the raw leachates is 1.260 $\mathrm{mg} / \mathrm{L}$ higher than that recorded in the landfills of the cities of Meknes [4], Oujda [5], Azzemour [8] and Agadir [10]. This shows that the leachates from Oum Azza are richer in organic matter and that treatment by aeration alone will not be enough to purify them. This significant burden was significantly reduced with aeration treatments to $840 \mathrm{mg} / \mathrm{L}$ and reverse osmosis to $42 \mathrm{mg} / \mathrm{L}$. The values obtained from BOD5 and COD of the raw leachate show that these effluents are in the biodegradation stage.

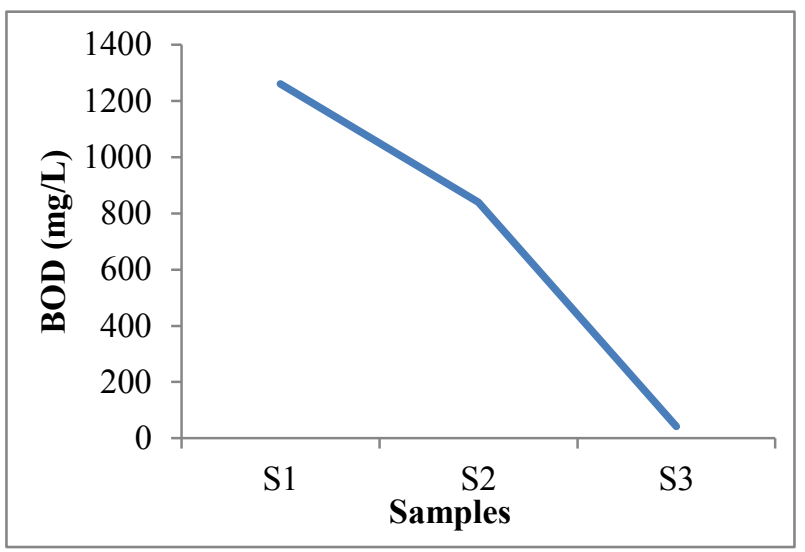

Figure 5: BOD5

The ratio COD/BOD5 determines the possibility and the degradation yield that can be expected from a biological oxidation treatment; it is equal to 0.52 , which shows that the leachate studied is a young leachate (ratio $>0.5$ ) and in methane generation phase ( $\mathrm{pH}$ 8.02). Indeed, according to Majraoua [4], a BOD5/COD ratio greater than 0.5 shows that the leachate is qualified as young. When this ratio is between 0.1 and 0.5 , the leachate is described as intermediate. However, if this ratio is very low $(<0.1)$, the leachate is considered to be stable [11]. This analysis shows the benefit of combining the biological aeration treatment with the physical reverse osmosis treatment for the Oum Azza leachate type [12].

\subsubsection{Suspended matters}

The variation of suspended matters in the leachates studied is shown in Figure 6. The suspended matters were present in large quantities in the raw leachate $(2280 \mathrm{mg} / \mathrm{L})$. This is a common feature of all garbage dumps [3]. At the outlet of the aerated basins, the biological treatment allowed the reduction of $40 \%$ of the suspended matters, thus going down to $1470 \mathrm{mg} / \mathrm{L}$. Then, it reached an average content of $97 \mathrm{mg} / \mathrm{L}$ after the inverse osmosis filtration, with a reduction rate of $88 \%$.

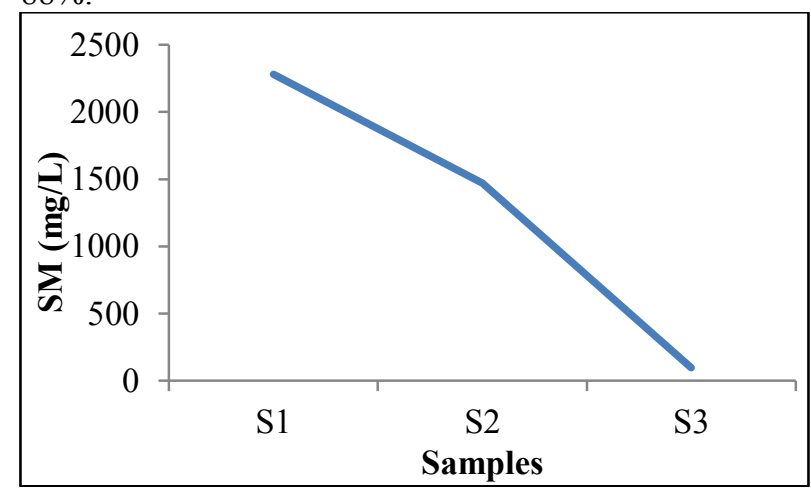

Figure 6: Suspended matters 


\subsubsection{Total organic carbon (TOC)}

The determination of TOC is a method of measuring the carbon content of dissolved and undissolved organic substances. Before treatment, the TOC was $1,640 \mathrm{mg} / \mathrm{L}$, then in the aeration basin it was 1,070 $\mathrm{mg} / \mathrm{L}$, and finally after the reverse osmosis treatment it was reduced to $62 \mathrm{mg} / \mathrm{L}$, with purifying efficiencies of $35 \%$ and $94 \%$, respectively (Table 2). This reduction rate achieved on an industrial scale at the Oum Azza LTC has also been reached at the experimental laboratory level by using another method of electrocoagulation treatment requiring an optimal temperature of $50^{\circ} \mathrm{C}$ [13], by combining a coagulationflocculation treatment with an adsorption treatment of activated carbon [7], and by using under optimal conditions an advanced Fenton and photo-Fenton oxidation process that can also significantly eliminate total organic carbon [3].

\subsection{Analysis of heavy metals}

The evolution of the concentrations of heavy metals in the leachates at the different phases of their treatment is illustrated in Table 3. The pollution parameters studied are the main heavy metals such as aluminum, lead, cadmium and copper. The concentration of aluminum is high in the $15.312 \mathrm{mg} / \mathrm{L}$ gross leachate, and remains high at the outlet of the 15.259 aeration tanks (15.259 $\mathrm{mg} / \mathrm{L}$ ). These values are higher than the values found in the Azemmour landfill [8]. This high concentration of aluminum could be related to the landfilling of objects such as electric accumulators and metal boxes. The concentrations of $\mathrm{Pb}, \mathrm{Cd}$ and $\mathrm{Cu}$ are higher compared to the concentrations found in the Azemmour landfill in samples S1 and S2 [8].

At the end of the treatments (S3), a reduction rate of $5 \%$ for lead is obtained, and at the exit of reverse osmosis, a reduction rate of $85 \%$ was recorded, $67 \%$ for copper, and $79 \%$ for cadmium. Lead was the most leachable metal fraction in a landfill, while copper was the most difficult to extract from the waste.

It seems clear that leachate aeration is not a useful treatment to reduce the concentrations of heavy metals. Indeed, Oygard et al. [14] reported that most of the heavy metals present in the leachates are in particulate form, and that the sedimentation treatment can be very effective in eliminating them. In our study, we have demonstrated that reverse osmosis filtration is effective for reducing the concentrations of heavy metals in leachates produced at the Oum Azza LTC in accordance with the national standards. Moreover, Vaverková et al. [15] have demonstrated the potential of a forest species of Basidiomycete fungi, Pleurotus ostreatus, in real-world applications to remove toxic heavy metals from leachate.

Table 3: Evolution of heavy metal concentrations in leachates at different stages of their treatment

\begin{tabular}{lllll}
$\begin{array}{l}\text { Samples / } \\
\text { parameters per } \\
\text { mg/L }\end{array}$ & $\begin{array}{l}\text { Leachates } \\
\text { unrefined } \\
\text { (youth) }\end{array}$ & $\begin{array}{l}\text { Leachates at the } \\
\text { outlet of the } \\
\text { aeration basin }\end{array}$ & $\begin{array}{l}\text { Leachates at the } \\
\text { exit of the } \\
\text { Reverse Osmosis }\end{array}$ & $\begin{array}{l}\text { Moroccan } \\
\text { standards }\end{array}$ \\
\hline Aluminium & $15.312 \pm 1.275$ & $15.259 \pm 1.420$ & $3.953 \pm 1.032$ & 1.10 \\
Lead & $1.591 \pm 0.203$ & $1.539 \pm 0.327$ & $0.367 \pm 0.101$ & 2.1 \\
Cadmium & $0.109 \pm 0.087$ & $0.107 \pm 0.065$ & $0.080 \pm 0.023$ & 3.025 \\
Copper & $1.017 \pm 0.105$ & $0.988 \pm 0.078$ & $0.468 \pm 0.012$ & 4.2 \\
\hline
\end{tabular}

\section{Conclusion}

The results of this study have allowed the evaluation of the performance level of the technical landfill site of the RSK Region, compared to other large LTCs of the Kingdom of Morocco, and the characterization of the liquid effluents that it generates. They have revealed the highest recycling and waste recovery potential in the country, reaching $20 \%$ of the HSW received with a target of $50 \%$ in the next 10 years. However, the Oum Azza LTC is the only one that has two sorting lines for recyclable waste and applies the deodorization and production techniques of the SRF valorized in the local cement industry.

Routine monitoring of leachate from controlled landfills is recommended to anticipate and avoid the risk of contamination of the receiving watershed on which many communities depend as a source of domestic water. It is also necessary to study the treatments to be applied to depollute this leachate [16].
These results have allowed us to demonstrate that the leachate is a young and unstable, carrying on the one hand a significant organic pollutant load, and on the other hand, a low load of metal pollutants, with the exception of Aluminum. In addition, they highlighted the relevance and effectiveness of the combination of biological aeration and inverse osmosis filtration treatment for the purification of this leachate. Pretreatment protects reverse osmosis, and the combination of those treatments seems to be an interesting technical and economic solution.

The treatment by aeration followed by reverse osmosis makes it possible to degrade pollutants and to clean out heavy metals to meet the Moroccan discharge standards for direct discharge waters. The reverse osmosis-generated concentrate is recycled to the landfill for spraying on buried solid waste layers and remains a long-term problem, particularly heavy metal infiltration. It can be concluded that the biological and reverse osmosis treatments are effective for organic 
leachate pollutants from the Oum Azza landfill, and make it possible to have a respective reduction rate of $33 \%$ and $95 \%$. However, reverse osmosis remains the most effective treatment for metal pollutants, allowing a reduction of up to $98 \%$ of their initial rate [12]. We still need to study the feasibility of these treatments for the large quantities of leachates stored on-site, especially the financial aspect. Finally, it would be judicious to study promptly the necessary modalities to reduce the humidity level of the HSW at the source, particularly at the location of their production, i.e. households, and at their transfer centers.

\section{Acknowledgments}

Our Acknowledgments would not be complete without thanking Mr. Said ZNIBER, managing director of the Moroccan-based PIZZORNO Group and CEO of the TAODEM corporation, in charge of the Oum Azza LTC, and his associates, especially Mrs. Faiza RHOUALEM, for their valuable help and support.

\section{References}

1. R. Benabou, Essais de caractérisation des déchets ménagers et assimilés réalisés au Maroc: résultats, synthèse et recommandations. Publié par la Coopération Municipale - Gouvernance locale et participative au Maghreb dénommée CoMun de la GIZ en collaboration avec la Direction Générale des Collectivités Locales. pp. 52-53, (2017).

2. E. Allix, Action publique locale et gestion des déchets des villes membres. Réseau Marocain de la Gestion des Déchets Urbains. Publié par la Coopération Municipale -Gouvernance locale et participative au Maghreb dénommée CoMun de la GIZ en collaboration avec la Direction Générale des Collectivités Locales, pp. 38-42, (2014).

3. I. El Mrabet, M. Kachabi, M. Nawdali, A. Harrach, F. Khalil, M. Ijjaali, H. Zaitan. Treatment of landfill leachate from Fez city (Morocco) using Fenton and photo-Fenton processes. In IOP Conference Series: Earth and Environmental Science, vol. 161, pp. 012025, (2018).

$4 . \quad$ Z. Mejraoua, N. Zine. Caractérisation Physico-Chimique des Lixiviats de la décharge sauvage de Meknès. European Scientific Journal, Vol. 13, pp. 154-166, (2017).

$5 . \quad$ S. Saadi, M. Sbaa, M. El Kharmouz. Caractérisation physico- chimique de lixiviats $d u$ centre d'enfouissement technique de la ville d'Oujda (Maroc oriental). Science Lib., Editions Mersenne, vol. 5, pp. 1-12, (2013).

$6 . \quad$ R. Hakkou, M. Wahbi, A. Bachnou, K. El Amari, L. Hanich, M. Hibti. Impact of Marrakech (Morocco) municipal landfill on water resources. Bulletin of Engineering Geology and the Environment. 60. 325-336, (2001).

7. Z. Chaouki, K. Fouad, M. Ijjaali, H. Valdés, S. Rafqah, M. Sarakha, H. Zaitan. Use of combination of coagulation and adsorption process for the landfill leachate treatment from Casablanca city. Desalination and Water Treatment, vol. 83, pp. 262-271, (2017).

8. E. El Bada, O. Assobhei, A. Kebbabi, R. Mhamdi, \& M. Mountadar. Caractérisation et prétraitement du lixiviat de la décharge de la ville d'Azemmour. Déchets, Sciences et Techniques Revue francophone d'écologie industrielle. 58, 30, 31, (2010).

9. MV. Kevbrina, AA. Okhapkina, DS. Akhlynin,IK. Kravchenko, AN. Nozhevnikova, VF. Gal'chenko. Growth of Mesophilic Methanotrophs at Low Temperatures. Microbiol, vol.70, pp. 384-391, 2001.

10. A. Jirouy, M.C. Harrouni, M. Belattar, M. Fatmi, S. Daoud. Traitement des lixiviats de la décharge contrôlée du Grand Agadir par aération intensive. Article. Rev. Mar. Sci. Agron. Vét. P. 60,61, (2014).

11. RM. Toklo, RG. Josse, N. Topanou, A. Togbe Pierre, P. Dossou-Yovo. Caractérisation physico-chimique des lixiviats d'une décharge : cas du lieu d'enfouissement sanitaire de Ouèssè-Ouidah (sud Bénin). International Journal of Innovation and Applied Studies vol. 13, pp. 921-928, (2015).

12. I. A. Tałałaj, P.Biedka, \& Bartkowska. Treatment of landfill leachates with biological pretreatments and reverse osmosis. Environnemental Chemestry Letters 17, 1177-1193. https://doi.org/10.1007/s10311-019-00860-6, (2019).

13. D. Sivakumar, J. Rajaganapathy, R. Anand,S. Mariavensa, S. Preethi. TOC and COD removal from municipal solid waste leachate using Electrocoagulation method. Journal of Chemical and Pharmaceutical Sciences, vol.8, pp. 745-749, (2015). 14. J.K. Oygard, E.H. Opedal. Assessment of dissolved and non-dissolved metals in aerated landfill leachate. Fresenius Environmental Bulletin, vol. 16, pp. 1451-1456, (2007).

15. M. D. Vaverková, D. Adamcová, M. Radziemska, S. Voběrková, Z. Mazur, J. Zloch. Assessment and evaluation of heavy metals removal from landfill leachate by Pleurotusostreatus. Waste and biomass valorization, vol. 9, pp. 503-511, (2018). 16. E. A. Tolulope, O. Temilola, J. O. Odiyo and J. N. Edokpayi. Physico-Chemical Analysis of Wastewater Discharge from Selected Paint Industries in Lagos, Nigeria. International Journal of Environnemental Research and Public Health. DOI : IJERPH 16, 1235. pp. 2-17, (2019).

Corresponding author: mheljalil@yahoo.fr 